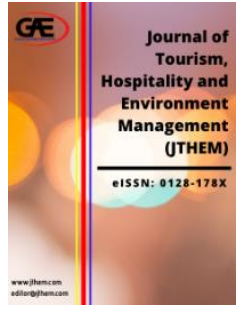

\author{
JOURNAL OF TOURISM, \\ HOSPITALITY AND \\ ENVIRONMENT MANAGEMENT \\ (JTHEM) \\ www.jthem.com
}

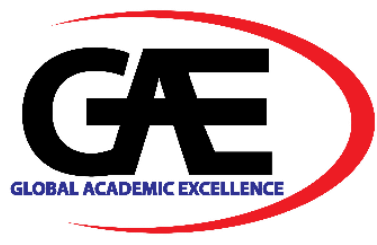

\title{
AN OVERVIEW OF THE LAND DEVELOPMENT ISSUES RELATED TO INDIGENOUS PEOPLES IN MALAYSIA
}

\author{
Kelvin Celesistinus $^{1 *}$, Siti Radiaton Adawiyah Zakaria ${ }^{2}$ \\ 1 Department of Real Estate, Faculty of Built Environment and Survey, Universiti Teknologi Malaysia \\ Email: kelvince04@gmail.com \\ 2 Department of Real Estate, Faculty of Built Environment and Survey, Universiti Teknologi Malaysia \\ Email: sradiaton@utm.my \\ Corresponding Author
}

\section{Article Info:}

Article history:

Received date: 01.10 .2021

Revised date: 01.11 .2021

Accepted date: 15.11 .2021

Published date: 01.12.2021

\section{To cite this document:}

Celesistinus, K., \& Zakaria, S. R. A. (2021). An Overview Of The Land Development Issues Related To Indigenous Peoples In Malaysia. Journal of Tourism Hospitality and Environment Management, 6 (26), 111-120.

DOI: $10.35631 /$ JTHEM.626009.

This work is licensed under $\mathrm{CC}$ BY 4.0 (c) (2)

\begin{abstract}
:
Given that the way of life of indigenous peoples is usually associated with low living standards, the government has an important role to play in ensuring that the gap between indigenous and non-indigenous communities is narrowed. Unfortunately, as the program to improve the quality of life of indigenous communities has been widely implemented across the country, tension has begun to escalate among the indigenous community on the real motive of the program. Government policy objectives to assimilate indigenous communities into mainstream society leave little scope for indigenous groups to pursue their own life projects. Several studies have reported that the development of the government within traditional indigenous lands has caused conflict between the developer and the indigenous community. This situation has caused the indigenous people to bear the consequences of losing their traditional land, which is very important to reflect their identity. The aim of this paper is therefore to examine the current issues related to the land development initiative on the way of life of indigenous peoples in Malaysia. Documents search from published and unpublished material is used for this paper and a guide with a set of settings five years prior. The findings of this paper show that the development of the government in indigenous traditional lands has disrupted the traditional way of life, leading to multiple adverse effects on the community and the environment. In other words, the core of the indigenous people's struggle to this date is therefore concentrated in their involvement in making decisions in any development proposed to enhance their quality of life. Apart from that, the perspective of land development between the government and the indigenous peoples is quite different from one another. In conclusion, it is important to elicit knowledge and opinion from both indigenous peoples and government agencies to ensure the impact of land development activities can be minimized and implemented appropriately.
\end{abstract}




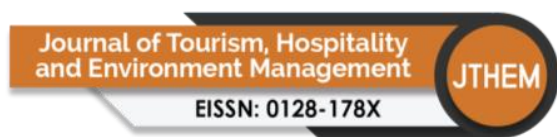

Volume 6 Issue 26 (December 2021) PP. 111-120

DOI 10/35631/JTHEM.626009

Keywords:

Indigenous Peoples, Government perspective, Land development Issues

\section{Introduction}

Given that the way of life of indigenous peoples is usually associated with low living standards, the government has an important role to play in ensuring that the gap between indigenous and non-indigenous communities is narrowed. Unfortunately, as the program to improve the quality of life of indigenous communities has been widely implemented across the country, tension has begun to escalate among the indigenous community on the real motive of the program. Government policy objectives to assimilate indigenous communities into mainstream society leave little scope for indigenous groups to pursue their own life projects. Several studies have reported that the development of the government within traditional indigenous lands has caused conflict between the developer and the indigenous community. This situation has caused the indigenous people to bear the consequences of losing their traditional land, which is very important to reflect their identity. The aim of this paper is therefore to examine the current issues related to the land development initiative on the way of life of indigenous peoples in Malaysia. Documents search from publish and unpublished material is used for this paper and a guide with a set of settings five years prior. The findings of this paper show that the development of the government in indigenous traditional lands has disrupted the traditional way of life, leading to multiple adverse effects on the community and the environment. In other word, the core of the indigenous people struggle to this date is therefore concentrated in their involvement in making decision in any development proposed to enhance their quality of life. Apart from that, the perspective of land development between the government and the indigenous peoples is quite different from one another. In conclusion, it is important to eliciting knowledge and opinion from both indigenous peoples and government agencies to ensure the impact of land development activities can be minimize and implemented appropriately.

\section{Literature Review}

There are three points will be discussed in the literature review. The review will begin with some introduction to the background of the Malaysian indigenous peoples, follow by the typology of the land development associate with the ideal development for the indigenous territory and the real intention of the land development initiate by the local government.

\section{Background of the Indigenous Peoples of Malaysia}

The term use to address the indigenous peoples of Malaysia is vary by region. In general, the indigenous peoples in Malaysia constituted of the 'Malays', 'Natives' and 'Aborigines or Orang Asli'. In other word, they also usually addressed as "Bumiputera" which refer to the "princes or sons of the soil",(Gomes, 2007; Khor and Zalilah Mohd Shariff, 2008; Khor and Shariff, 2019) and the classification has been used as a fundamental for affirmative action and policies in their favor, including the reservation of places for them in the civil service.

In peninsula Malaysia, the indigenous constituted of Malay indigenous and the Orang Asli. A Malay is one who professes the religion of Islam, habitually speaks the Malay language and conforms to Malay customs. As for the "Aborigine or Orang Asli", the definition of the term Copyright (C) GLOBAL ACADEMIC EXCELLENCE (M) SDN BHD - All rights reserved 


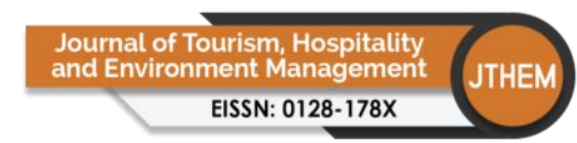

Volume 6 Issue 26 (December 2021) PP. 111-120

DOI 10/35631/JTHEM.626009

is not quite specific where the Federal Constitution defines an 'aborigine' only as 'an aborigine of the Malay Peninsula'. However, a more details on who is 'aborigine' a mentioned in section 3(2) of the Aboriginal Peoples Act 1954. A person can be considered aborigine if one or both of their parents was a member of aboriginal ethnic group, speaks an aboriginal language and habitually follows an aboriginal way of life, customs and beliefs. While in Sabah and Sarawak, the indigenous are known as 'Native'. In Sarawak, a person can be considered 'native' if both of their parents are natives whereas in Sabah, a native is a citizen, the child or grandchild of a person of a race indigenous to Sabah, was born either in Sabah or to a father domiciled in Sabah at the time of the birth. However, under state laws it is possible for a person who is not born as a native to be deem a native by applying to the native court or by virtue of residence, assimilation into the culture of a native community, good conduct and language.

\section{Typology of Indigenous Land Development}

According to the Organization for Economic Co-operation and Development (OECD, 2019), the indigenous development can further be classified into four type considering the number of people inhabit the area. The following typology of indigenous development in rural areas outlines for ideal types:

a) Remote Indigenous communities with abundant natural resources and amenities - these places consider to have the opportunities for commercial development related to minerals, hydrocarbons, renewable energy, fishing and aquaculture, food production, and nature-based tourism. A key issue for these communities will be how to invest ownsource revenues in ways that support economic value adding and diversification, and building/attracting the necessary skills to support business growth, while promoting the sustainable management of resources for future generations.

b) Remote Indigenous communities where natural resources and amenities are limited or absent - these places lack natural resources available for commercial use, and economic development is limited to the internal market and some tourist opportunities. In these places government transfers, subsistence hunting and fishing, and local bartering and sharing through partnerships or service agreements with neighboring communities and/or other Indigenous groups will play a greater role in supporting community wellbeing.

c) Indigenous communities close to cities abundant natural resources and amenities these places consider having the potential to development related to renewable energy, food production, and tourism. A key issue for these communities will be integrating with the wider urban/regional economy and governance arrangements to maximize the benefit of their resource base.

d) Indigenous communities close to cities where natural resources and amenities are limited or absent - these places are close to cities but do not have sufficient land size or the natural resources that enable commercial scale development opportunities. However, even land parcels are small, this may still present opportunities for retail and industrial land development, and collaboration with local municipalities on planning and infrastructure is important to activating these opportunities.

Based on the above development opportunity for indigenous peoples, location is indeed playing huge roles in any kind of economic development. Rural areas especially in remote area cover a variety of agricultural lands and forests. While relatively isolated from the mainstream 


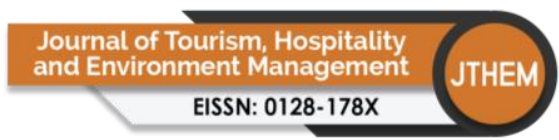

Volume 6 Issue 26 (December 2021) PP. 111-120

DOI 10/35631/JTHEM.626009

economy, these areas do have large natural, cultural and historic resources that can be the basis for economic development.

\section{Behind the Development Initiatives}

Indigenous development can be implemented through either the restructured settlement, economic development or social development program. Restructured settlement program is an approach that involves the regrouping and restructuring of the indigenous community. The initial objective of the program was merely to enable them to be more easily managed (Mustaffa Omar, 2009). While the economic development and social development program tend to focus on transforming the indigenous community lifestyle to more sustainable lifestyle. Initially, main objective of the mentioned program above is to reduce the gap between the indigenous and the non-indigenous community either in economic or social development.

Considering the indigenous territories happen to be storing abundance of natural resources, modern states still tend to eye indigenous lands as terra nullius available to be taken for national security purposes, to house burgeoning non-indigenous populations, or to be exploited for wealth or development. As for private companies, their often alliance with the states, covet the riches from natural resources to be accrued from indigenous territories.

Given the fact that the way of life of indigenous peoples is usually associated with low living standards, the government does play an important role in ensuring that the gap between indigenous and non-indigenous communities can be narrow down (Mattos, 2015). The continue effort of the government to enhance the quality of life of the indigenous community can be seen based on the community capital such as follows;

a) Physical Capital: Improving physical capital includes focusing on community assets such as public facilities, water and sanitation provision, efficient transport, safe and high-quality housing, adequate infrastructure, and telecommunications.

b) Human Capital: Increasing human capital requires a focus on areas such as health, education, nutrition, literacy, and family and community cohesion, as well as on increased training and improved workplace dynamics to generate more productive and innovative workers; basic determinants of health such as peace and safety, food, shelter, education, income, and employment are necessary prerequisites.

c) Economic Capital: Strengthening economic capital means focusing on maximizing the use of existing resources.

d) Natural Capital: Minimizing the consumption of essential natural capital means living within ecological limits, conserving and enhancing natural resources, using resources sustainably (soil, air, water, energy, and so on). 


\begin{tabular}{|c|c|c|}
\hline & & DOI 10/35631/JTHEM.62600 \\
\hline $\begin{array}{c}\text { Community Capital } \\
\text { Social Capital } \\
\text { Human Capital } \\
\text { Financial/Built } \\
\text { Capital } \\
\text { Natural Capital } \\
\text { Political Capital } \\
\text { Culture Capital }\end{array}$ & $\begin{array}{l}\text { Government } \\
\text { Intervention } \\
\text { Impetus for } \\
\text { Community } \\
\text { Economic } \\
\text { Development as a } \\
\text { strategy to change } \\
\text { the community } \\
\text { characteristic }\end{array}$ & $\begin{array}{l}\frac{\text { Outputs and }}{\text { Outcomes }} \\
\text { Positive changes in } \\
\text { community } \\
\text { characteristic }\end{array}$ \\
\hline
\end{tabular}

\section{Figure 2.1: Overview of The Government Strategies of Community Development} Efforts

(Adapted from Mattos, 2015)

\section{Discussion}

To this date, the indigenous peoples have suffered from the consequences of historic injustice, including colonization, dispossession of their lands, territories and resources, oppression and discrimination as well as lack of control over their own ways of life (United Nation, 2009; Jalata, 2013; Errico, 2017). The Malaysian Commission on Human Rights have reported that in handling indigenous development, the government does not conduct proper consultations in implementing development within the indigenous territories. This approach has caused many destruction to the indigenous territories and the scale of destruction may vary according to the desired development goals but the effect is often the same which affecting the indigenous traditional way of life (Gudynas, 2018).

These policies toward resettlement and planned economic activities implement by the government is inconsistent with indigenous rights to determine their own priorities for development and to the recognition of lands. Economic development and 'mainstreaming' indigenous peoples should not come at the price of jeopardizing the indigenous way of life as determined by them. Unfortunately, the execution of land development attempts by the government often in a manner that is not appropriated leading to the devastating to the indigenous land, culture, identity, and overall wellbeing.

Priorities for national development, particularly those affecting the indigenous community are continue to be introduced and implemented without effective cooperation and consultation with the indigenous peoples in an effort to push them into the mainstream economy. The lack of nuanced and equitable economic development programs adversely affects the indigeneity and identity of rural-based indigenous communities.

Therefore, to address the lack of authority over land development within the indigenous territories, the Declaration on the Rights of Indigenous Peoples stress that states require to consult with the indigenous peoples concerned in order to obtain their free, prior and informed consent before adopting and implementing legislative or administrative measures that may 


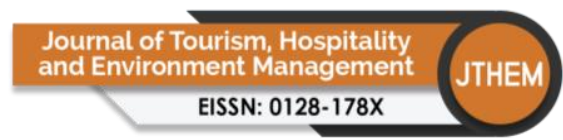

Volume 6 Issue 26 (December 2021) PP. 111-120

DOI 10/35631/JTHEM.626009

affect them. For example, the Declaration explicitly requires States to obtain consent of indigenous peoples in cases of:

i. The relocation of indigenous peoples from their lands or territories (article 10)

ii. The adoption of legislation or administrative policies that affect indigenous peoples (article 19)

iii. The storage or disposal of hazardous materials on indigenous peoples' lands or territories (article 29)

iv. The undertaking of projects that affect indigenous peoples' rights to land, territory and resources, including mining and other utilization or exploitation of resources (article 32).

Unfortunately, the right to be consult and obtain free, prior and informed consent has not happened for most indigenous peoples in Malaysia thus widening the gap between the rich and the poor (World Bank Group, 2016), with indigenous populations the one who falling behind. Development on a worldwide scale has not reduced poverty and in some countries has stopped altogether (United Nations, 2020).

The ignorance of the opinion of the indigenous people toward the development scheme plan for them has caused harm to the indigenous way of life where the harm might have indirectly or directly to their cultural and spiritual value (Nordin and Ibrahim, 2014). This may be seen at a fundamental level where the government fails to fully engage the indigenous peoples in their own solutions, recognizing existing cultural values and priorities, thus resulting to force an implementation to enhance wellbeing.

However, the failure to involve the indigenous people in decision making is not entirely subjected to the government action but also often related to their indigenous value that very difficult to ascertain and justify by the governments toward the allocation of resources as they were not yet willing to quantified their resources (Nguyen and Cairney, 2013).

As mention by Wycliffe Antonio et al. (2019), the view of the indigenous toward their customary land is not only subjected to tangible assets but also have a special emotional, cultural and spiritual element. This might have to do which the sense of belongings and attachment to the land, which symbol their identity. In fact, the majority of indigenous peoples around the globe technically have similarities in terms of culture and lifestyle that highlight spiritual relationships with the environment (UN Environment Programme, 2017; World Resources Institute, 2018). There is no denying that these relationships can take many forms, but in general, these relationships are rooted in the sense of belonging and respect to nature (Sangha et al., 2015; Chan et al., 2016).

For Indigenous people, culture or spiritual is consider as the foundation upon which everything else is built. Culture underpins all aspects of life including connections to family and community, connection to country, the expression of values, symbols, cultural practices and traditional and contemporary forms of cultural expression such as indigenous language, ceremonies, cultural events, storytelling, dance, music and art. This connection will remain even though some of the indigenous people are no longer live on the particular traditional land. 


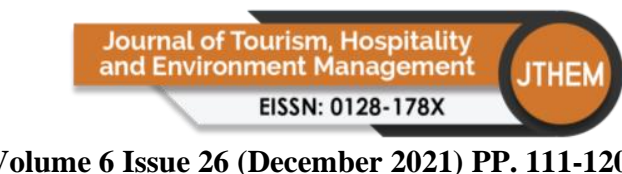

Volume 6 Issue 26 (December 2021) PP. 111-120

DOI 10/35631/JTHEM.626009

Indigenous people describe the land as sustaining and comforting, fundamental to their health, their relationships and their culture and identity.

On the other hand, the government see it as a major resource to be extracted for development or human purposes (Sangha et al., 2018; Antonio and Griffith-Charles, 2019; Kamaljit K Sangha et al., 2019; Kamaljit K. Sangha et al., 2019). The land occupied by the indigenous communities often has great economic and development opportunity, but this particular area was often bound by customary restrictions (Parlee, 2015).

Therefore, most economic development programs implemented in rural areas often adversely affect the culture, economy, social, and way of life of indigenous people due to no consensus can be reached. The modern economies continue to disregard the function of nature's services toward improving well-being (Costanza et al., 2014). The 're-engineered economy' is based on economic growth, which typically disregarding the relationship between human and nature. In fact, since entering the industrialization era, the indicator to measure the national growth is concentrated in Gross Domestic Product, which basically ignores others aspect (Costanza et al., 2014; Daly, 2015)

\section{Conclusion}

In conclusion, the main core of the indigenous people struggle to this date is concentrated in their involvement in making a decision in any development proposed to enhance their quality of life. The indigenous were even criminalized for traditional activities. According to the Europe Union, the traditional practice that has been continually practised by the indigenous people are inseparable from their livelihood, and further action to make them leave this routine will affect their behaviour. The denial of long passing traditional practices and displacement away from traditional territories has led to another kind of global issues related to the "Identity Crisis".

Traditional land is not necessarily a barrier to development, but the success of land development scheme would be more prevalent if the indigenous community itself had control over their development (Nelson, 2019). Rather than forcedly drag to adapt new lifestyle, which totally deviated from their tradition, a hybrid way of life that balanced out the element of cultural and modernity can be achieve if the government can engage more sustainable approach.

\section{References}

Ab.Hadi, M. Y. et al. (2013) 'Poverty Eradication through Vocational Education (Tourism) among Indigenous People Communities in Malaysia: Pro-poor Tourism Approach (PPT)', Procedia - Social and Behavioral Sciences, 93, pp. 1840-1844. doi: 10.1016/j.sbspro.2013.10.127.

Abdullah, J. et al. (2016) 'Living Conditions in Orang Asli Resettlement Project (PROSDET) of Pantos, Pahang, Malaysia', Procedia - Social and Behavioral Sciences, 222, pp. 143150. doi: 10.1016/j.sbspro.2016.05.204.

Abdullah, J., Borhan, M. A.-A. and Ahmad, C. B. (2015) 'Orang Asli Resettlement in Urban Environment at Bukit Lanjan, Selangor, Malaysia', Procedia - Social and Behavioral Sciences, 201(February), pp. 71-79. doi: 10.1016/j.sbspro.2015.08.132. 


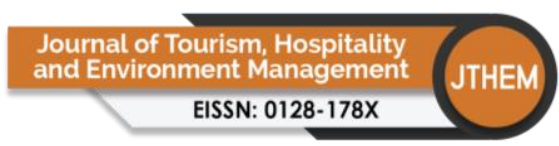

Volume 6 Issue 26 (December 2021) PP. 111-120

DOI 10/35631/JTHEM.626009

Aeria, A. (2016) 'Andrew Aeria Economic Development via Dam Building: The Role of the State Government in the Sarawak Corridor of Renewable Energy and the Impact on Environment and Local Communities Center for Southeast Asian Studies , Kyoto University Center for Southeas', Southeast Asian Studies, 5(3), pp. 373-412. Available at: doi: 10.20495/seas.5.3_373.

Alias, A. and Daud, M. N. (2012) 'Compensation for Orang AsH native land in Malaysia: The perceptions and challenges in its quantification', Journal of Design and Built Environment, Volume 4(Issue 1), pp. 63-84.

Antonio, W. and Griffith-Charles, C. (2019) 'Achieving land development benefits on customary/communal land', Land Use Policy, 83(February), pp. 124-133. doi: 10.1016/j.landusepol.2019.02.005.

Chan, K. M. A. et al. (2016) 'Why protect nature? Rethinking values and the environment', Proceedings of the National Academy of Sciences of the United States of America, 113(6), pp. 1462-1465. doi: 10.1073/pnas.1525002113.

Costanza, R. et al. (2014) 'Development: Time to leave GDP behind', Nature, 505(7483), pp. 283-285. Available at: http://www.nature.com/news/development-time-to-leave-gdpbehind-1.14499.

Daly, H. (2015) Economics for a Full World, Great Transition Initiative.

Errico, S. (2017) Identification of Indigenous Peoples and Recognition of Their Rights : Human rights-based overview of nationallegal and policy frameworks against the backdrop of country strategies for development and poverty reduction, International Labour Organization.

Gomes, A. G. (2007) Modernity and Malaysia: Settling the Menraq forest nomads, Modernity and Malaysia: Settling the Menraq Forest Nomads. doi: 10.4324/9780203960752.

Gudynas, E. (2018) 'Extractivisms: Tendencies and consequences', Reframing Latin American Development, pp. 61-76. doi: 10.4324/9781315170084.

Jalata, A. (2013) 'The impacts of English colonial terrorism and Genocide on indigenous/ Black Australians', SAGE Open, 3(3), pp. 1-12. doi: 10.1177/2158244013499143.

Kenney-Lazar, M. and Ishikawa, N. (2019) 'Mega-plantations in southeast asia landscapes of displacement', Environment and Society: Advances in Research, 10(1), pp. 63-82. doi: 10.3167/ares.2019.100105.

Khor, G. L. and Shariff, Z. M. (2019) 'Do not neglect the indigenous peoples when reporting health and nutrition issues of the socio-economically disadvantaged populations in Malaysia', BMC Public Health, 19(1), pp. 1-5. doi: 10.1186/s12889-019-8055-8.

Khor, G. L. and Zalilah Mohd Shariff (2008) 'The Ecology of Health and Nutrition of " Orang Asli " ( Indigenous People ) Women and Children in Peninsular Malaysia', Tribes and Tribals, Special Vo(2), pp. 66-77.

Lunkapis, G. J. (2013) 'Confusion over land rights and development opportunities through communal titles in Sabah, Malaysia', Asia Pacific Viewpoint, 54(2), pp. 198-205. doi: 10.1111/apv.12019.

Mattos, D. (2015) 'Community Capitals Framework as a Measure of Community Development', Cornhusker Economics.

Nelson, R. (2019) 'Beyond Dependency: Economic Development, Capacity Building, and Generational Sustainability for Indigenous People in Canada', Environment \& Development, 9(3), pp. 1-8. doi: 10.1177/2158244019879137. 


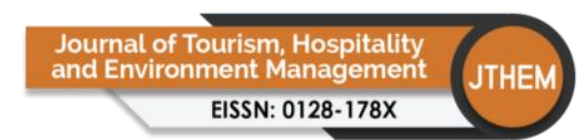

Volume 6 Issue 26 (December 2021) PP. 111-120

DOI 10/35631/JTHEM.626009

Nguyen, H. T., Pham, T. H. and de Bruyn, L. L. (2017) 'Impact of hydroelectric dam development and resettlement on the natural and social capital of rural livelihoods in bo hon village in central vietnam', Sustainability (Switzerland), 9(8), pp. 1-15. doi: $10.3390 /$ su9081422.

Nguyen, O. K. and Cairney, S. (2013) Literature review of the interplay between education, employment, health and wellbeing for Aboriginal and Torres Strait Islander people in remote areas: working towards an Aboriginal and Torres Strait Islander wellbeing framework, CRC-REP Working Paper CW013. Available at: http://www.crcrep.com.au/resource/CW013_InterplayLiteratureReview_TowardsWellbeingFramewo rk.pdf.

Nordin, R. and Ibrahim, M. S. (2014) 'Exercising the principle of free, prior and informed consent (FPIC) in land development: An appraisal with special reference to the Orang Asli in peninsular Malaysia', Pertanika Journal of Social Science and Humanities, 22(January), pp. 183-204.

OECD (2019) Linking Indigenous C ommunities with Regional Development 2019.

Parlee, B. L. (2015) 'Avoiding the Resource Curse: Indigenous Communities and Canada's Oil Sands', World Development, 74, pp. 425-436. doi: 10.1016/j.worlddev.2015.03.004.

Sangha, K. K. et al. (2015) 'Ecosystems and indigenous well-being: An integrated framework', Global Ecology and Conservation, 4(July), pp. 197-206. doi: 10.1016/j.gecco.2015.06.008.

Sangha, K. K. et al. (2018) 'An ecosystem services framework to evaluate indigenous and local peoples' connections with nature', Ecosystem Services, 31, pp. 111-125. doi: 10.1016/j.ecoser.2018.03.017.

Sangha, Kamaljit K et al. (2019) 'Recognising the role of local and Indigenous communities in managing natural resources for the greater public bene fi $\mathrm{t}$ : Case studies from Asia and Oceania region', Ecosystem Services, 39(June), p. 100991. doi: 10.1016/j.ecoser.2019.100991.

Sangha, Kamaljit K. et al. (2019) 'Recognising the role of local and Indigenous communities in managing natural resources for the greater public benefit: Case studies from Asia and Oceania region', Ecosystem Services, 39(August), p. 100991. doi: 10.1016/j.ecoser.2019.100991.

Scheyvens, R. et al. (2017) 'Indigenous entrepreneurship on customary land in the Pacific: Measuring sustainability', Journal of Management and Organization, 23(6), pp. 774785. doi: $10.1017 /$ jmo.2017.67.

UN Environment Programme (2017) Indigenous people and nature: a tradition of conservation, UN Environment Programme. Available at: https://www.unenvironment.org/news-and-stories/story/indigenous-people-andnature-tradition-conservation.

United Nation (2009) State of the World's Indigenous Peoples, New York. Available at: http://www.cinu.org.mx/pueblosindigenas/docs/Informe_Completo_Ingles.pdf.

United Nations (2020) Inequality in a Rapidly Changing World, World social report 2020.

World Bank Group (2016) Taking on Inequality, Poverty and Shared Prosperity Report 2016. doi: 10.1017/cbo9780511720079.004.

World Comission of Dams (2000) Dams and Development on Dams: A New Framework for Decision-Making, Report.

World Resources Institute (2018) For Indigenous Peoples, Losing Land Can Mean Losing Lives, World Resources Institute. Available at: 
Volume 6 Issue 26 (December 2021) PP. 111-120 DOI 10/35631/JTHEM.626009

https://www.wri.org/blog/2018/05/indigenous-peoples-losing-land-can-mean-losinglives.

Yates, B. (2011) 'Displaced Indigenous Malaysians Face Uncertain Future', United Nation University, Available at: https://ourworld.unu.edu/en/displaced-indigenousmalaysians-face-uncertain-future. 